\title{
Biological technique of protection of crops: prospects for Ukraine
}

Krutjakova V. ${ }^{1}$, Hulych O. ${ }^{2}$, Pylypenko L. ${ }^{3}$

1. 'Engineering-technological institute "Biotekhnika» of NAAS, Mayatska doroga, 26, Khlibodarske, Biliayevskyi region, Odesa oblast, 67667, Ukraine, ${ }^{3}$ Institute of protection of plants of NAAS, Vasylkivska Str., 33, Kyiv, 03022, Ukraine; e-mail: 1, ${ }^{2}$ biotechnica.od@gmail.com, 3ililya.pylypenko@gmail.com

The purpose. To analyze modern state of application of biological technique of protection of crops in Ukraine and its regions, development of domestic production of biological products in the context of world experience and prospects of application of biomethod, basic trends of development of this market and prospects of ecological farming agriculture. Methods. Analytical, economic-statistical, comparative analysis, graphical and cartographical. Results. In the last years in Ukraine there was a resistant negative trend of dominance of chemical methods of protection of crops above biological. Thus situation in regions is different: if in 2016 the average index of share of biological technique in total amount of application of means of protection of crops across Ukraine was 4,6\%, then in 9 regions this parameter was above and oscillated from 5,0 up to $13,0 \%$; in the majority of regions the share of biomethod did not exceed $1-3 \%$, and in 5 areas had not reached 1\%. Regions with the greatest cultivated areas of crops head antiratings on application of biological techniques of protection of crops with the volumes which do not exceed 5\% of cultivated areas (Dnipropetrivsk, Zaporizhzhia, Kharkiv, Mykolaiv, Kirovograd, Odesa, Kherson oblasts). Conclusions. In Ukraine application of ecologically safe biological technique of protection of crops tends to the further reduction. For overcoming this situation they offer the most comprehensible scripts: eurointegration - implementation of organic legislation of EU and increasing areas under organic farming up to $1,2 \%$, under ecological - up to $1,6 \%$ of all area occupied under farmproduction; national - formation and legal maintenance of organic farming, maintenance of national system of collective safeguard of both organic and ecological farming agriculture and increasing areas under organic farming up to $1,2 \%$, under ecological - up to $5,6 \%$ of all areas occupied under farmproduction.

Key words: protection of plants, biological and integrated methods, ecologization of farming agriculture, organic farming, biological means.

https://doi.org/10.31073/agrovisnyk201811-20

Introduction. Prospects for the development of the agrarian sector of Ukraine's economy and the growth of its export potential depend on the quality of agriculture. products, its compliance with European and international standards.

Efficiency of agricultural production products in modern conditions to a large extent depends on the successful use of protection means s.-g. crops from pests, diseases and weeds, which ensures the crop is saved from natural losses and increases the overall yield of agricultural crops. cultures.

One of the decisive factors in ensuring high agricultural production standards is the reduction of the use of chemicals and the widespread introduction of environmentally sound technologies into the agricultural production process. The prospect of becoming the basis of environmentalization of agricultural production has a biological method of plant protection as an integrated method of a wide range of activities, the result of which is:

- protection of seeds and plants from diseases and pests;

- increase of resistance of plants to phytopathogens;

- Improving plant nutrition and increasing their yields;

- stimulation of plant growth and development by biologically active compounds;

- reduction of losses of agricultural land products from diseases and pests during storage and transportation; 
- Improving the structure and soil fertility;

- increase of ecological stability of agrocenoses;

- general improvement of the ecological state of the environment and public health.

In the practice of applying the methods of protection of agricultural crops present both chemical methods and biological. Their ratio depends on many factors, the main of which should be attributed: the general culture and traditions of agriculture; state policy regarding environmental protection, in particular soil; development of organic farming; stimulation of production of agricultural products of high quality and increase of export potential of the agrarian sector of the state economy.

High-efficiency modern agrarian production envisages an increase in the share of agricultural production. high quality products requiring the transition to integrated crop protection methods, the refusal of aggressive chemical methods with harmful side effects on the environment and human health.

In Ukraine, certain legal, organizational and economic prerequisites for the wide introduction of environmentally sound methods of plant protection: biological and integrated; however, today the area of their distribution and application is extremely insignificant.

The importance of the biological method of plant protection in the process of ecologization of agricultural production while at the same time critically low their practical application in Ukraine sets out a number of requirements regarding the methods and methods of applying a biometector in conditions of heterogeneity of agroproduction processes, a wide range of biologics, including complex action, and different degrees of efficiency at the same time low the personal awareness of agricultural producers of the need for the transition to biological and integrated methods of protection. In these conditions the importance of scientific substantiation and scientific confirmation of the effectiveness of the biometector, especially in the long run, is growing.

It should be noted that biological plant protection products have been known to science for quite some time (from the seventeenth to eighteenth centuries). However, their use on an industrial scale began in the 50's of the last century and since then has been developing at an accelerated pace. For this period, the basic intensity of the initiated scientific researches in this sphere falls. However, it should be noted that they concerned, in most cases, the biological aspects of the problem and were carried out by biologists: Fedorenko VP [1], Tkalenko AM [1, 5, 6], Konversa V.P. [1], Akimov IA, Zerova MD, Kolodochka LI [2], Fursov VM [3], Shelestova VS, Padi MM, Goncharenko O.I. [4], Gordh G. [7], Li Liying [8], Van Lenteren J. C., Roskam M. M., Timmer R. [9], Dunham William C. [10] and many others. The scientific study of the aspects of the use of the biometector in the domestic agrarian sector of the economy was not sufficiently paid attention, due to which the unsolved features and problems of the use of biological means of protection in the village of .g. crops by agricultural producers in different regions of the country, in different protection systems, the problems of production of biopreparations are not disclosed, etc.

The purpose of research. Analyze the current state of application of the biological method of protection s.-g. cultures in Ukraine and in some of its regions, the development of domestic production of biopreparations in the context of world experience and world perspectives on the application of biometrics, the main trends in the development of world markets for bioproducts and the prospects of ecological agriculture.

Materials and methods of research. For conducting analytical, economic-statistical and comparative studies the information of the State Statistics Service of Ukraine, the State Committee for Statistics of Ukraine and analytical publications of domestic and foreign authors was used. Graphic and cartographic representations of research results are made using Microsoft Office Excel 2003 - 2007 and CoreLDRAW X5.

Research results. The importance of solving the problems of the biomethode will only increase, especially in the context of world strategies and development trends. For example, the practical implementation of the provisions and recommendations of the United Nations proclaimed global sustainable development strategy has intensified the biomethosis process in the EU, the USA and most other developed agrarian countries of the world. At the same time in agriculture the priority was given to 
the direction of integrated biologization of agriculture and production of agricultural products and food of higher ecological quality without the use of chemical pesticides and mineral fertilizers of industrial origin.

Significant result of this activity is the formation of a powerful world market of environmentally friendly agricultural products and food, the capacity of which has already exceeded 50 billion dollars. USA and has a definite tendency for further growth.

Particularly these processes became more active in the 1990s - in the early 2000s. It is during this period that the vast majority of companies in the production of biological products present on the world market of biofuels [10] (Figure 1).

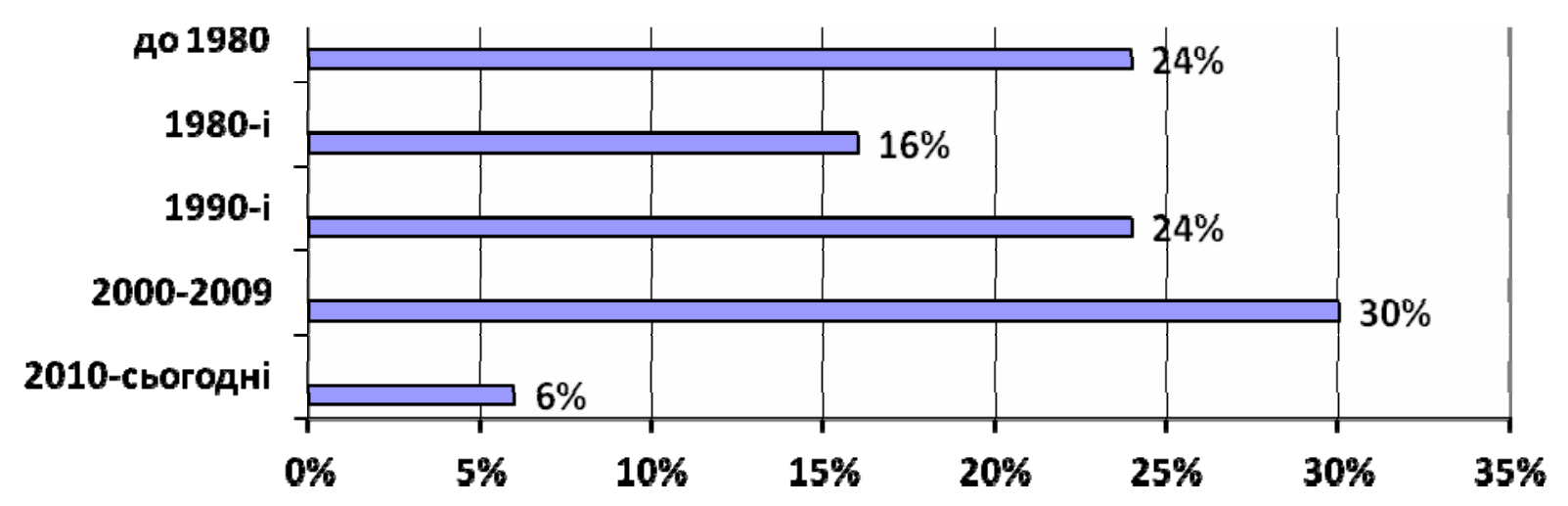

Figure 1 - Establishing companies for the production of biological remedies plants (by Dunham William C., 2015)

The production and use of biological means of plant protection over the last twenty years has shown a steady tendency for further growth, and today the world market of bioproducts has turned out to figures of 3 billion dollars. USA (table 1). This is a thirty-fold increase to the 1993 figures and a doubling of biomass volumes (in value terms) over the past four years.

Table 1 - Indicators of the world market for bioproducts

(million USD)

\begin{tabular}{|c|c|c|c|c|c|c|c|c|c|}
\hline Year & 1993 & 1999 & 2005 & 2009 & 2012 & 2014 & 2016 & $\begin{array}{c}2020 \\
\text { (forecast) }\end{array}$ & $\begin{array}{c}2025 \\
\text { (forecast) }\end{array}$ \\
\hline $\begin{array}{c}\text { Production of } \\
\text { bioproducts }\end{array}$ & 100 & 250 & 500 & 1000 & 1500 & 2000 & 3000 & 4000 & 7500 \\
\hline
\end{tabular}

* It is made according to the data given in [10].

According to the forecasts of scientists in the near future, the market of bioproducts will continue to grow at an accelerated pace and will reach 4 billion dollars. US in 2020 and $\$ 7.5$ billion. USA - in 2025 This will be facilitated by the transition of agricultural production to the principles of sustainability, the expansion of production of ecological (organic) agricultural products, the gradual transition to a broad biologization of agro-industrial processes while the refusal of chemical means of plant protection and mineral fertilizers of industrial production.

Leading countries and organizations that focus their efforts on the abandonment of traditional intensive technologies in agriculture and the introduction of plant biotechnology technologies with the production of environmentally friendly products and food products for its processing, are simultaneously and actively engaged in innovative activities in the field of production of means of biologization of agriculture.

Today, the share of biological farming in most countries of the European Community (excluding Eastern European countries) reaches $9-12 \%$ with the prospect of its bringing in the next years to $17-25 \%$. Similar processes take place in the USA, Mexico, Australia, India, Japan. Over the past few years, the most massive measures to increase production and the formation of organic agricultural markets have been carried out in China. 
In general, annual growth of production of biological means of plant protection, nutrition and stimulation of growth of crops at the level of $12-17 \%$ is projected.

In Ukraine, certain legal, organizational and economic prerequisites for the wide introduction of environmentally sound methods of plant protection: biological and integrated; however, today the area of their distribution and application is extremely insignificant.

In the 90 years of the last century in Ukraine, good conditions were created for the widespread use of the biological method of protecting crops as the most organic and appropriate agroecoccinosis. Given the development of the domestic agricultural sector by the biological method of agricultural crop protection today, Ukraine would have a significant export potential of agricultural products of high quality and would considerably strengthen its position in the agrarian world markets. However, to my great regret, this did not happen.

In recent years, there has been a steady negative trend in the domination of chemical methods of protecting agricultural crops over biological substances in Ukraine, with a negligible share (in the range of 4-5\%) of the total use of agricultural crops in farms.

Reducing the use of the biological method occurred both in relative indicators, and in absolute (table 2, figure 2). If in 1995 the protection of agricultural crops by biological methods was carried out on 3023 thousand hectares, which was $15,2 \%$ of all areas where protection of crops was carried out, then the area of application of biological methods decreased and, for example, in 2016 amounted to 2,056 thousand hectares $(4,6 \%$ of all areas $)$.

Table 2 - Volume of application of chemical and biological methods of protection of crops from pests, diseases and weeds in farms of Ukraine

\begin{tabular}{|c|c|c|c|c|}
\hline \multirow{2}{*}{ Year } & $\begin{array}{c}\text { Volumes of } \\
\text { application of } \\
\text { methods of protection } \\
\text { of agricultural crops, } \\
\text { total thousand ha }\end{array}$ & $\begin{array}{c}\text { including, thousands of hectares } \\
\text { chemical }\end{array}$ & $\begin{array}{c}\text { The share of biological } \\
\text { methods } \\
\text { methods }\end{array}$ & $\begin{array}{c}\text { mods } \\
\text { volume of protection } \\
\text { of crops, } \%\end{array}$ \\
\hline 1995 & 19824 & 16801 & 3023 & 15,2 \\
\hline 2000 & 12970 & 11916 & 1054 & 8,1 \\
\hline 2010 & 38588 & 36533 & 2055 & 5,3 \\
\hline 2011 & 45856 & 43527 & 2329 & 5,1 \\
\hline 2012 & 45191 & 43057 & 2134 & 4,7 \\
\hline 2013 & 47535 & 45527 & 2008 & 4,2 \\
\hline 2014 & 45586 & 43304 & 2282 & 5,0 \\
\hline 2015 & 43816 & 41630 & 2186 & 5,0 \\
\hline 2016 & 45173 & 43117 & 2056 & 4,6 \\
\hline
\end{tabular}

* According to the State Committee for Consumer Goods of Ukraine.

At the same time, the use of chemical methods of protecting crops in Ukrainian farms intensified and increased by almost three times over the same period: from 16,801 thousand hectares in 1995 to 45,527 thousand hectares in 2013 and 43,117 thousand hectares in 2016 (table 2).

In the context of regions, the situation with the application of the biological method of protection of crops significantly varies. With the average indicator in 2016, the share of the biological method in the total volumes of application of means of protection of agricultural crops in 4,6\% in Ukraine, in nine regions this indicator was higher and ranged from $13,0 \%$ in Chernihiv and $11,2 \%$ in Cherkasy regions to $5,0 \%$ - in the Volyn region. In the vast majority of regions in 2016, the share of the biological method did not exceed $1-3 \%$, and in the five regions did not reach $1 \%$ : Dnipropetrovsk region - 0,05\%, Zaporozhye - 0,2 \%, Kharkiv - 0,4 \%, Donetsk - 0,6 \%, Lugansk - 0,8 \% (table 3). 
For these regions and the area of application of the biological method were insignificant: Dnipro oblast - 0,2 thousand hectares, Zaporozhye - 4,2 thousand hectares, Lugansk - 5,2 thousand hectares, Donetsk $-8,2$ thousand hectares, Kharkiv - 8,4 thousand hectares.

Table 3 - Share of the biological method in the total volumes of application of means of protection of crops by regions of Ukraine in 2016

\begin{tabular}{|c|c|c|c|c|c|}
\hline \multirow[b]{2}{*}{$\begin{array}{c}\text { № } \\
\text { by } \\
\text { order }\end{array}$} & \multirow[b]{2}{*}{ Region * } & \multirow[b]{2}{*}{$\begin{array}{l}\text { The scope } \\
\text { of application } \\
\text { of remedies, } \\
\text { thousands } \\
\text { of hectares }{ }^{1}\end{array}$} & \multicolumn{2}{|c|}{ including: } & \multirow[b]{2}{*}{$\begin{array}{l}\text { The share of the } \\
\text { biological method } \\
\text { of protection in } \\
\text { total volumes, } \%\end{array}$} \\
\hline & & & $\begin{array}{l}\text { chemical } \\
\text { method of } \\
\text { protection, } \\
\text { thousands } \\
\text { of hectares }^{1}\end{array}$ & $\begin{array}{l}\text { biological } \\
\text { method of } \\
\text { protection, } \\
\text { thousands of } \\
\text { hectares }^{1}\end{array}$ & \\
\hline & Ukraine & 45173,0 & 43117,0 & 2056,0 & 4,6 \\
\hline 1 & Chernihiv region & 1620,2 & 1410,1 & 210,1 & 13,0 \\
\hline 2 & Cherkassy region & 2595,0 & 2303,1 & 291,9 & 11,2 \\
\hline 3 & Kievskaya region & 1994,6 & 1818,0 & 176,6 & 8,9 \\
\hline 4 & Chernivtsi region & 618,2 & 566,7 & 51,5 & 8,3 \\
\hline 5 & Poltava region & 3407,2 & 3135,4 & 271,8 & 8,0 \\
\hline 6 & Sumy region & 2234,7 & 2070,9 & 163,8 & 7,3 \\
\hline 7 & Khmelnitsky region & 3197,7 & 2972,6 & 225,1 & 7,0 \\
\hline 8 & Rivne region & 1051,4 & 986,2 & 65,2 & 6,2 \\
\hline 9 & Volyn region & 1027,2 & 975,8 & 51,4 & 5,0 \\
\hline 10 & Zakarpatsk region & 324,6 & 310,2 & 14,4 & 4,4 \\
\hline 11 & Ternopil region & 2000,2 & 1912,1 & 88,1 & 4,4 \\
\hline 12 & Ivano-Frankivsk region & 580,4 & 559,6 & 20,8 & 3,6 \\
\hline 13 & Zhytomyr region & 1433,5 & 1387,5 & 46,0 & 3,2 \\
\hline 14 & Kherson region & 1908,5 & 1848,7 & 59,8 & 3,1 \\
\hline 15 & Kirovograd region & 2072,8 & 2008,9 & 63,9 & 3,1 \\
\hline 16 & Vinnitsa region & 3939,6 & 3825,6 & 114,0 & 2,9 \\
\hline 17 & Odessa region & 3389,8 & 3316,7 & 73,1 & 2,2 \\
\hline 18 & Lviv region & 1363,4 & 1345,9 & 17,5 & 1,3 \\
\hline 19 & Nikolaev region & 2057,4 & 2033,4 & 24,0 & 1,2 \\
\hline 20 & Lugansk region & 733,6 & 727,9 & 5,7 & 0,8 \\
\hline 21 & Donetsk region & 1403,5 & 1395,3 & 8,2 & 0,6 \\
\hline 22 & Kharkiv region & 2286,8 & 2278,4 & 8,4 & 0,4 \\
\hline 23 & Zaporozhye region & 2202,4 & 2198,2 & 4,2 & 0,2 \\
\hline 24 & Dnipropetrovsk region & 1729,5 & 1729,3 & 0,2 & 0,0 \\
\hline
\end{tabular}

Note: * the regions are located in the order of reduction of the share of the biological method of protection of crops in total volumes in 2016. ${ }^{1}$ According to the State Committee for Consumer Goods of Ukraine.

The largest areas of application of the biological method of protection of crops in 2016 were in the central and northern regions of Ukraine: Cherkasy region - 291,9 thousand hectares, Chernihiv region 210,1 thousand hectares, Kiev region - 176,6 thousand hectares, Sumy region - 163,8 thousand hectares, Vinnytsya region - 114,0 thousand hectares (table 3).

Absolute indicators of the application of the biological method of protection of crops give a general picture of the scope of their application (area of application). However, it should be noted that the regions differ, and very significantly, in the sown area of agricultural crops, for which, in fact, and the methods of 
protection are applied. Therefore, the indicator of application of the biological method of protection relative to the crop area of agricultural crops is more representative. Calculations of volumes of application of the biological method of crop protection in 2015 and 2016 are presented in table 4 and figure 2.

Table 4 - Volumes of application of the biological method of protection of agricultural crops by regions of Ukraine in 2015, 2016

\begin{tabular}{|c|c|c|c|c|c|c|c|}
\hline \multirow{3}{*}{$\begin{array}{l}\mathrm{N} \\
\text { by } \\
\text { order }\end{array}$} & \multirow{3}{*}{ Region* } & \multirow{2}{*}{\multicolumn{2}{|c|}{$\begin{array}{c}\text { Sown area of } \\
\text { agricultural crops, } \\
\text { thousands of hectares }\end{array}$}} & \multicolumn{4}{|c|}{$\begin{array}{c}\text { Обсяги застосування біологічного } \\
\text { методу захисту с.-г. культур }\end{array}$} \\
\hline & & & & \multicolumn{2}{|c|}{ тис. га ${ }^{2}$} & \multicolumn{2}{|c|}{ \% від посівної площі } \\
\hline & & $\begin{array}{l}2015 \\
\text { years }\end{array}$ & $\begin{array}{l}2016 \\
\text { years }\end{array}$ & $\begin{array}{l}2015 \\
\text { years }\end{array}$ & $\begin{array}{l}2016 \\
\text { years }\end{array}$ & $\begin{array}{l}2015 \\
\text { years }\end{array}$ & $\begin{array}{l}2016 \\
\text { years }\end{array}$ \\
\hline & Ukraine & 26901,8 & 27026,0 & 2186,0 & 2056,0 & 8,13 & 7,61 \\
\hline 1 & Dnipropetrovsk region & 1934,1 & 1920,2 & 1,0 & 0,2 & 0,05 & 0,01 \\
\hline 2 & Odessa region & 1842,4 & 1846,2 & 143,1 & 73,1 & 7,77 & 3,96 \\
\hline 3 & Kharkiv region & 1750,0 & 1760,4 & 14,2 & 8,4 & 0,81 & 0,48 \\
\hline 4 & Poltava region & 1719,8 & 1719,6 & 216,1 & 271,8 & 12,57 & 15,81 \\
\hline 5 & Kirovograd region & 1680,5 & 1692,7 & 74,4 & 63,9 & 4,43 & 3,78 \\
\hline 6 & Vinnitsa region & 1639,1 & 1642,2 & 145,4 & 114,0 & 8,87 & 6,94 \\
\hline 7 & Zaporozhye region & 1623,9 & 1630,2 & 7,9 & 4,2 & 0,49 & 0,26 \\
\hline 8 & Nikolaev region & 1563,1 & 1533,4 & 19,3 & 24,0 & 1,23 & 1,57 \\
\hline 9 & Kherson region & 1383,4 & 1351,4 & 63,9 & 59,8 & 4,62 & 4,43 \\
\hline 10 & Chernihiv region & 1181,4 & 1196,2 & 165,5 & 210,1 & 14,01 & 17,56 \\
\hline 11 & Cherkassy region & 1200,6 & 1194,9 & 286,1 & 291,9 & 23,83 & 24,43 \\
\hline 12 & Kiev region & 1153,0 & 1164,0 & 201,8 & 176,6 & 17,50 & 15,17 \\
\hline 13 & Khmelnitsky region & 1130,3 & 1153,2 & 299,1 & 225,1 & 26,46 & 19,52 \\
\hline 14 & Sumy region & 1113,9 & 1122,3 & 130,8 & 163,8 & 11,74 & 14,60 \\
\hline 15 & Donetsk region & 978,8 & 989,6 & 1,4 & 8,2 & 0,14 & 0,83 \\
\hline 16 & Zhytomyr region & 852,1 & 881,6 & 43,2 & 46,0 & 5,07 & 5,22 \\
\hline 17 & Ternopil region & 793,4 & 812,2 & 94,1 & 88,1 & 11,86 & 10,85 \\
\hline 18 & Lugansk region & 782,9 & 786,3 & 0,2 & 5,7 & 0,03 & 0,72 \\
\hline 19 & Lviv region & 638,3 & 662,0 & 32,1 & 17,5 & 5,03 & 2,64 \\
\hline 20 & Volyn region & 537,6 & 552,3 & 67,4 & 51,4 & 12,54 & 9,31 \\
\hline 21 & Rivne region & 545,6 & 547,8 & 99,3 & 65,2 & 18,20 & 11,90 \\
\hline 22 & Ivano-Frankivsk region & 365,0 & 371,4 & 15,3 & 20,8 & 4,19 & 5,60 \\
\hline 23 & Chernivtsi region & 305,3 & 305,7 & 48,7 & 51,5 & 15,95 & 16,85 \\
\hline 24 & Zakarpatsk region & 187,3 & 190,2 & 16,0 & 14,4 & 8,54 & 7,57 \\
\hline
\end{tabular}

Note: * The regions are located in the order of descending crop area in 2016. 'Statistical collection "Regions of Ukraine", 2016 / State Statistics Service of Ukraine / ed. IM Beetle; answer for the issue MB Timonina - Part II - K., 2016. - 692 p. - S. 268,269; Squares, gross collections and yields of crops, fruits, berries and grapes (final data) in 2016: stat. Bulletin / State Statistics Service of Ukraine / Responses. for the issue OHM. Prokopenko - K., 2017. - 186 p. - P. 48. [Electronic resource]. - Mode of access: www.ukrstat.gov.ua. ${ }^{2}$ According to the State Committee for Consumer Goods of Ukraine. 


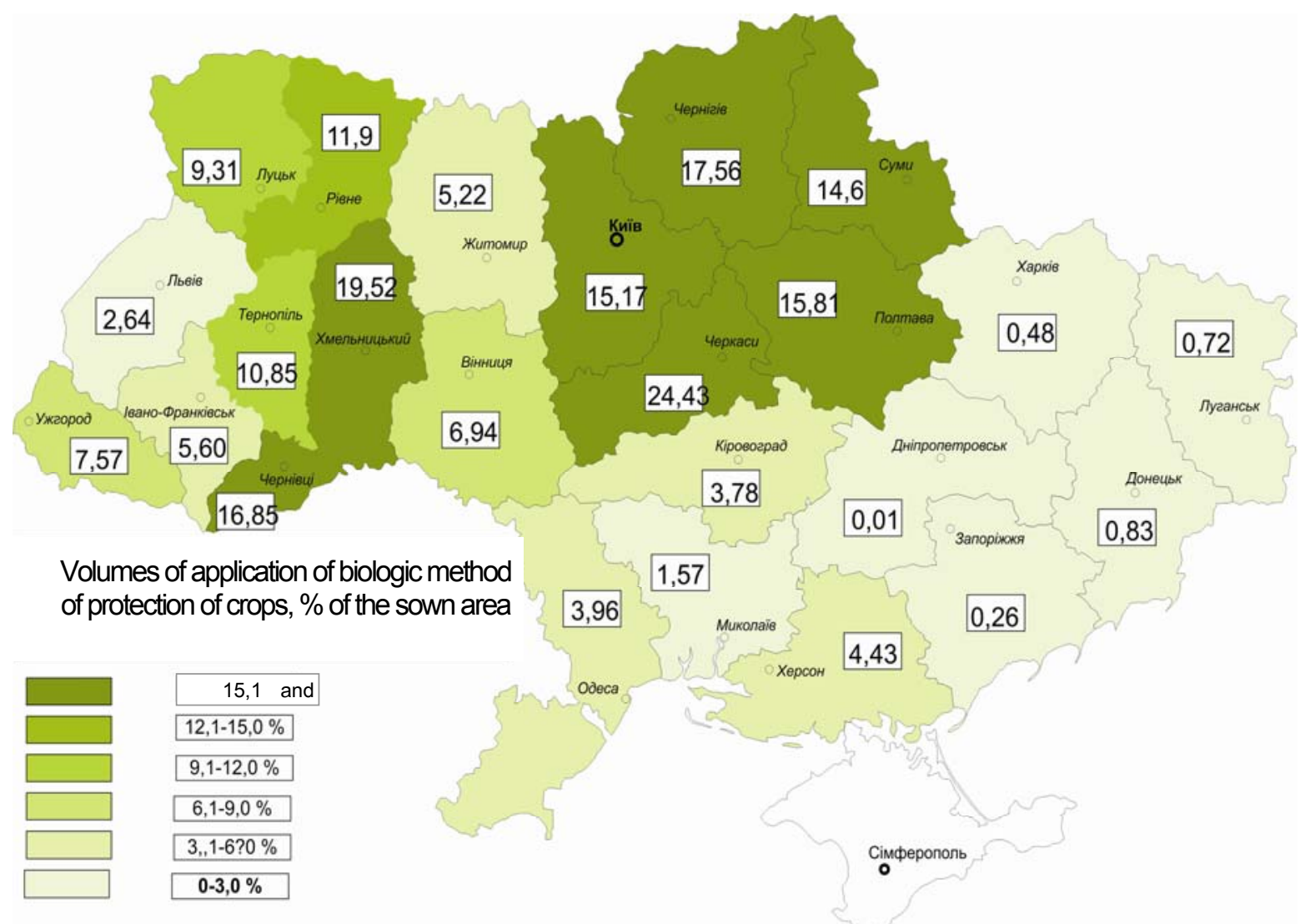

Figure 2 - Volume of application of the biological method of protection of agricultural crops by regions of Ukraine, $\%$ of the sown area

Conclusions and perspectives of further searches in this direction. The conducted researches of volumes of application of the biological method of protection of crops in 2015 and 2016 give an opportunity to confirm certain tendencies and make the following conclusions:

- in Ukraine, the use of an ecologically safe biological method of protection of crops for a long time (since 1995) is at an extremely low level and tends to further decrease: in $2016-7,61 \%$ of the sown area of agricultural land. crops (in $2015-8,13 \%$ );

- The best situation with the use of the biological method of protection of crops in Cherkassy, Khmelnytsky, Chernigov, Chernivtsi, Poltava, Kiev, Sumy, Rivne, Volyn regions. The volumes of the use of the biological method in 2016 ranged from $24,43 \%$ of the crop area of agricultural crops in the Cherkassy region, 19,52 \% in Khmelnytsky, 17,56 \% in Chernihiv, and 9,31\% in the Volyn region. The same regions were among the leaders in 2015 , with the only difference that Cherkasy, Chernigiv, Poltava, Sumy, Chernivtsi regions increased the use of the biological method of protection of crops, while in other regions the use of biomethos decreased;

- regions with the largest crop area of agricultural crops are headed by anti-ratings for the application of biological methods of protection of crops with volumes not exceeding $5 \%$ of sown areas: Dnipropetrovsk Oblast - 0,01\% in $2016(0,05 \%$ in 2015) ; Zaporizhzhya - 0,26 \% in $2016(0,49 \%$ in 2015); Kharkiv - 0,48\% in 2016 (0,81 \% in 2015); Nikolaev - 1,57 \% in 2016 (1,23\% in 2015); Kirovogradskaya - 3,78 \% in 2016 (4,43 \% in 2015); Odesa - 3,96 \% in 2016 (7,77\% in 2015); Kherson city $-4,43 \%$ in 2016 (4,62 \% in 2015). The reduction in 2016 compared with the previous year 2015, and the so meager volumes of the biotechnology for the protection of agricultural crops, suggests consolidating the dominance of chemical methods over biological ones, which inevitably will result in negative side effects in agrocenoses and, consequently, losses in the agrarian sector of the economy.

In Ukraine, biological drugs are used to protect plants of different spectrum of action: against pests, against diseases, to increase crop, to fix atmospheric nitrogen, to mobilize hard-to-reach phosphorus, to stimulate growth, against pests and pathogens, against rodent-like mice. Microbiological preparations of 
bacterial and fungal origin, as well as entomologic preparations, were the most widely used. The mass production of these agents began at the end of the last century, when an extensive network of biofacies and biolabsorpts was created.

There is a tendency to increase the range of microbiological remedies that are included in the "List of pesticides and agrochemicals in Ukraine". A significant share in the overall structure is made up of drugs intended to improve nutrition and increase the yield of crops $-28,8 \%$. Their number has significantly increased in comparison with previous years: from 17 to 28 preparations. Increased number of biologics and for the protection of crops against pathogens (19 drugs versus 11 in previous years) - 19,6\%. For the protection of crops from pests included 13 drugs, representing $13,4 \%$ of the total, for the control of rodents - three drugs $(3,1 \%)$. The share of biopreparations intended to improve atmospheric nitrogen utilization by plants is $27,8 \%$ (27 preparations), to increase phosphorus mobilization - 5,1 \% (5 preparations).

Currently, according to the Ministry of Agrarian Policy and Food of Ukraine, there are 25 biofacies and biolabs, and their total number, taking into account private sector production (according to own estimates), is over 45.

Prospects for the development of biologization products are determined by various factors. First of all, its development is stimulated by an increase in the demand of agricultural producers, an expansion of areas under ecological agriculture, which includes all kinds of alternative agricultural systems, which can be divided into two groups: organic and ecological. According to forecasts ETI "Biotechnica" NAAS of Ukraine is expected to increase by 2025 the area: under organic farming from 1,0 to 1,2\%, and under the ecological - from 1,6 to $5,6 \%$.

In the National Report "The Objectives of Sustainable Development: Ukraine" among the specified tasks, it is envisaged "to increase the area of organic production land from 410,6 thousand hectares $(1,0$ $\%$ of the total area of agricultural land) in 2015 to 3000.0 thousand hectares $(1,7 \%$ the total area of agricultural land) in 2030" [11].

The solution to this problem must be accompanied by the expansion of the scope and practice of the application of biological methods of plant protection, which for organic production are the only acceptable methods of plant protection against pests and diseases.

In agricultural production, the replacement of synthetic pesticides with biological substances will make it possible to reduce soil contamination with chemical pesticide residues, stop the growth of resistance of pests to plant protection, restore and improve soil quality, increase agricultural productivity and improve the quality of its storage.

The executive authorities, which ensure the formation and implementation of state policy in the field of plant protection, are faced with the task of gradually increasing the share of biological and integrated methods of plant protection in general volumes, the transition to environmentally sound technologies of growing agricultural products, reducing the excessive loading on the natural environment due to reduced chemicalization agricultural production, including chemical methods of agricultural crop protection. This, in turn, will require a critical rethinking of the priority tasks for the implementation of the policy of ecologization of agricultural production, the development of mechanisms for stimulating the transition to biological and integrated methods of crop protection, the development of new environmentally safe technologies in crop production, storage and transport of agricultural production, the development of a wide network of biofacies and biolabs, new scientific research on biologization of plant protection.

This, in turn, will require a critical rethinking of the priority tasks for the implementation of the policy of environmentalization of agriculture in the broad context and the formation of a common culture of environmentally-friendly agricultural production. These tasks include:

- development of normative legal acts regulating production and application of biological means of plant protection;

- formation of a common culture of environmentally-friendly agricultural production, creation of a system of training personnel with the skills of application of biological preparations of plant protection; 
- development of mechanisms for stimulating the transition to biological and integrated plant protection methods;

- development of new eco-safe technologies in crop production, storage and transportation of agroproduction products;

- development of a wide network of biofacies and biolabs;

- conducting new scientific studies on the biologization of plant protection and developing mechanisms for their implementation into practice;

- development of a strategy and state program for the development of the biological method of plant protection.

An important task is to change the attitude towards the biomethod among agricultural producers. For this purpose, it is important to popularize the method at all levels of the educational process, to make extensive use of the media and exhibitions.

The process of environmentalization of agriculture can take place in different scenarios. However, in our opinion, the most acceptable are Euro-integration and national ones. According to these scenarios, there are some differences in the ultimate objectives of environmentalizing agriculture and the means to achieve them.

\section{Conclusions}

European integration: the implementation of organic EU legislation and the bringing of areas under organic farming up to $1,2 \%$ and under ecological agriculture to $1,6 \%$ of all areas occupied by agricultural production.

National: formation and legal support of organic agriculture, provision of the national system of collective guarantee of organic and ecological agriculture, and the bringing of areas under organic farming up to $1,2 \%$ and under ecological agriculture to $56 \%$ of all areas occupied by agricultural production.

The realization of these tasks will return to Ukraine the image of one of the leading countries over the past years on the practical biologization of protection of agricultural crops against pests and diseases. For this purpose, there are all the grounds and possibilities for realization.

\section{References}

1. Fedorenko V.P., Tkalenko A.N., Konverskaya V.P. (2009). Dostizheniya i perspektivy razvitiya biologicheskogo metoda zashchity rasteniy $\vee$ Ukraine.[Achievements and prospects of development of the biological method of plant protection in Ukraine]. Karantin i zakhist roslin. No 6. P. 6 - 9. [In Russian].

2. Akimov I.A., Zerova M.D., Kolodochka L.I. (1997). Fundamental'nye issledovaniya paraziticheskikh i khishchnykh chlenistonogikh i ikh rol' $v$ razvitii biologicheskikh metodov zashchity rasteniy.[ Fundamental studies of parasitic and predatory arthropods and their role in the development of biological methods of plant protection]. Vestnik zoologii. No 1 - 2. P. 5 - 15. [In Russian].

3. Fursov V.N. (2001). Biologicheskiy metod zashchity rasteniy: mezhdunarodnye issledovaniya i prioritetnoe znachenie taksonomii. [Biological method of plant protection: international research and taxonomy priority]. Vestnik zoologii. No 35 (3). P. 97 - 101. [In Russian].

4. Shelestova V.S., Padii M.M., Honcharenko O.I. (1999). Biolohichnyi zakhyst. [Biological protection]. Zakhyst roslyn. No 10. P. 2 - 5. [In Ukrainian].

5. Tkalenko A. (2011). Biometod - zalog polucheniya kachestvennoy produktsii. [Biomethod - the key to obtaining quality products]. Ogorodnik. No 5. P. 14 -16. [In Russian].

6. Tkalenko Hanna. (2013). Biopreparaty v borotbi zi shkidnykamy.[ Biopreparats in the fight against pests]. Ahrobiznes sohodni. No 4(251). URL: http://agro-bussines.com.ua/agro/ahronomiiasohoddni/item/302-biopreparaty-vborotbi-zi-shkidnykamy.html [In Ukrainian].

7. Gordh G. (1982). Taxonomic recommendations concerning new species important to biological control. International J. Entomology. No 1. P. $15-19$. 
8. Liying Li, Wajberg Ed.E., Hassan S.A. (1995). Worldwide use of Trichogramma for biological control on different crops: a survey. Biological Control with Egg Parasitoids. Wallingford: CABI, P. 37 - 53.

9. Van Lenteren J.C., Roskam M.M., Timmer R. (1997). Commercial mass production and pricing of organisms for biological control of pests in Europe. Biological Control. 10. P. $143-149$.

10. Dunham W.C. (2015). Evolution \& Future of Biocontrol, Basel, URL: http://dunhamtrimmer.com/wp-content/uploads/2015/11/Bill-Dunham-2BMonthly-Evolutijn-Future-ofBiokontrol-Industriycopy.pdf

11. Tsili Staloho Rozvytku: Ukraina. Natsionalna dopovid.[ Sustainable Development Goals: Ukraine. National report]. Ministerstvo ekonomichnoho rozvytku i torhivli Ukrainy. 2017. Kyiv. 176 p. [In Ukrainian]. 